\title{
Pre- and Post-Urban Wetland Area in Dhaka City, Bangladesh: A Remote Sensing and GIS Analysis
}

\author{
M. Sufia SULTANA ${ }^{\mathbf{1}^{*}, \mathbf{2}}$, G. M. Tarekul ISLAM ${ }^{\mathbf{1}}$, Zahidul ISLAM ${ }^{\mathbf{2}}$ \\ ${ }^{1}$ Institute of Water and Flood Management, Bangladesh University of Engineering and Technology, \\ Dhaka, Bangladesh \\ ${ }^{2}$ Bangladesh Space Research and Remote Sensing Organization (SPARRSO), Sher-e-Banglanagar, \\ Dhaka, Bangladesh \\ "E-mail: mail.sufia@gmail.com
}

Received August 12, 2009; revised September 28, 2009; accepted October 21, 2009

\begin{abstract}
Landscape of Dhaka city - one of the fastest growing mega cities in the world, is undergoing continuous changes and modifications due to progressive urbanization. Pre- and post-urban changes of water bodies in the city were studied using aerial photographs and SPOT images in GIS environment. In 1968, the total area of marshy and peaty inundated low-lying areas was $133 \mathrm{~km}^{2}$, which was depicted to be $67 \mathrm{~km}^{2}$ in the year 2001. The total area of inland lakes as estimated from the aerial photos of 1968 was $5.1 \mathrm{~km}^{2}$ which became $1.8 \mathrm{~km}^{2}$ in the year 2001 as seen in SPOT image. More than $50 \%$ of the wetland area reduced over the period 1968 to 2001 . Changes of the water body mostly occurred in the regions where majority of the urban expansion took place. The urban infrastructures filled and/or compartmentalized the water bodies, causing water loggings problem during wet-season in various part of the city. Development and alteration of the existing water bodies should consider the natural hydrological conditions so that the changes can cope with the artificial intervention.
\end{abstract}

Keywords: Wetland, Dhaka City, Bangladesh, Remote Sensing, GIS

\section{Introduction}

Urbanization is the major demographic development which is occurring very fast and with larger magnitude in the developing countries. In many cases, specifically, in the poor economic countries urbanization is a demand driven unplanned and bottom up process, which transforming the existing landscape without considering the possible consequences and requirement for environmental sustainability [1]. These urban growths have profound adverse effect on the water resources, particularly in the humid tropical region [2]. In the tropical region where monsoon causes huge rainfall during some part of the year are naturally drains by the gravity drainage through stream-river networks, and wetlands works as natural retention storage. Urbanization, particularly unplanned one, hampered this natural state of drainage, and hence causes sudden inundation and waterlogging. However, hydrological consideration during urban planning can reduce the adverse effects through conservation of wetlands and stream-networks to be used as retention ponds and canals or designing such elements to drainstore-drain the modified landscape $[3,4]$.
Dhaka city, the capital of Bangladesh, is situated in the central part of the country. It has one of the fastest urban growth rates among the developing countries $[5,6]$ and home to more than 10 million people [7]. The landform of the city is characterized by the Madhupur Tract - an elevated Pleistocene terrace [8] that stands higher than the neighbouring floodplain and low-lying marshlands. The land cover of the city is being modified extensively by the progressive urbanization [5]. The rapid rise in urban population is a major drive to the development of infrastructure and services, including road-network, water supply, sanitation, sewerage and drainage services and hence expansion of the city towards the surrounding floodplain and low-lying areas.

The relief controlled landforms of the area were efficiently drained via streams and canals (local term 'khals') [9] to the floodplain and low-lying area and ultimately to the downstream via large rivers. These canals, wetlands and depressions have been filled up by new urbanization, both in and around the built-up city area [9-11]. These unplanned urbanizations have been destroying the water-bodies and flow-paths causing rainfall-flooding and drainage congestion in many locations in the city $[10,12$, 
13]. Filling activities, embankments and roads are being compartmentalized the wetlands and water bodies and hence obstructed the natural drainage. There is a general observation that the wetlands and other water bodies in Dhaka city is greatly reduced over the decades due to progressive urbanization $[10,14]$. There were number of studies mentioned about the land filling activities and their effects on the drainage congestion and water logging $[10,11,15-17]$. The city at the moment, particularly, during the heavy downfall in the wet-season gets water logged [17]. The scenario would be worsening with time as erratic and intense rainfall events postulated [18] to be increasing their frequencies due to climate change [6]. A recent report in a daily newspaper (The Prothom Alo, A national Bengali newspaper, $29^{\text {th }}$ of July 2009) supports the intense and erratic rainfall events to occur in the recent time as well. "It said that on the $28^{\text {th }}$ of July 2009 there was $333 \mathrm{~mm}$ rainfall over 9 hours which was similar to $104 \mathrm{~mm}$ over 3 hours on the $4^{\text {th }}$ of August 2004. Both the events caused severe flooding which lead to a city-wide disruption, and took several days to recedes the water. These events lead the policy maker to think to restore the natural drainage canals and wetlands, which are in many cases filled or modified at the current time.',

Rivers around the city gets the storms-drainage and other low grade (mostly households) liquid waste, and also liquid waste from the industries. These liquids and other pollutants have been polluting the river water, see in [19]. Wetlands of the city could play a significant role in reducing the pollutants loads if the wetlands were designed as retention basin $[4,20,21]$ for the urban drainage to the rivers. Plants and soils in wetlands play a significant role in purifying water, removing high levels of nitrogen and phosphorus, and in some cases, removing toxic chemicals through biogeochemical cycling and storage [4].

However, there are very few studies $[12,13]$ have been done on the changes of the wetlands in the city. Chowdhury et al. [12] pointed on the elimination of local water storage and consequences in the mid-central western part of Dhaka city. Reza and Alam [13] showed the changes of wetlands in the western half of the city. Both the studies concentrated on the western part of the city while none look over the whole city specifically, to the eastern part. History of urban growth [17,22] in the region demonstrates that the city is being expanding to the eastern part, low-lying areas, in the recent decades. These urban expansions are mostly occurring on to the wetlands in the eastern part, which were suggested to act as retention basin for urban drained water [9]. It is evident from the literature that the floodplains and low-lying areas were not under any sort of urban infrastructure during 1960s and urban growth in the area boosted during the 1990s. The objective of the present work is to map and distinguish the differences of the water bodies between the pre-
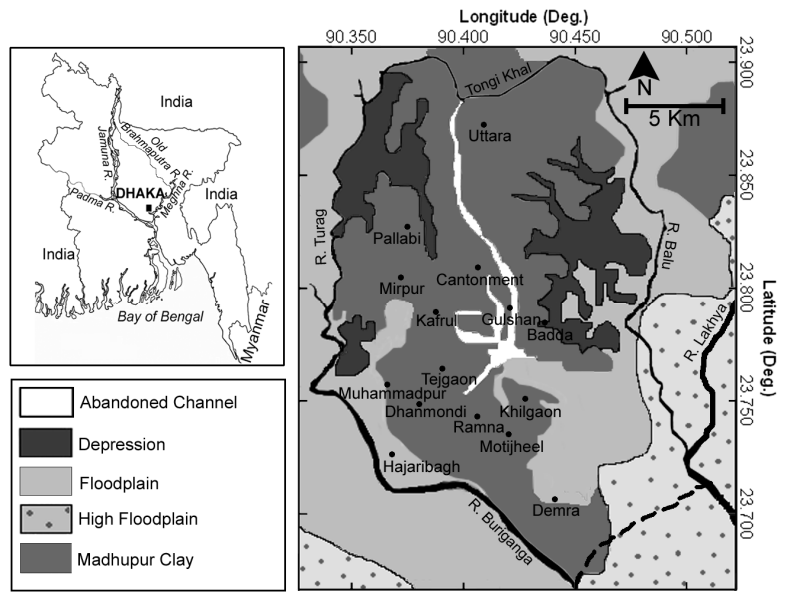

Figure 1. Study area along with prominent landform types (adopted from ref 23). In the figure Dhaka is shown in Bangladesh context (upper left box) and legends for the different landform in the lower left box. Major police-stations were marked. Analysis is done for the area $\left(298 \mathrm{~km}^{2}\right)$ bordered by the rivers except lower-right corner where border is demarcated by a dashed line.

pre- and post-urbanization in Dhaka city. In this context an aerial photograph of the year 1968 (as pre- urbanization) and satellite imagery of 2001 (as post urbanization) were used to map and quantify the disparity between water bodies applying remote sensing and GIS as a tool. An aerial photograph for the year 1968 was chosen because of the unavailability (at least with the current source) of a satellite image for that time.

\section{Natural Setting and Geomorphology}

Dhaka with an aerial extent of $298 \mathrm{~km}^{2}$, bounded by the Buriganga River in the south, the Balu River in the east, the Tongi Khal in the north and the Turag River in the west (Figure 1). These rivers are connected to the Ganges-Brahmaputra River system (locally known as the Padma-Meghna-Jamuna River system and also include the Old Brahmaputra river) flowing towards southeast from the all sides of the bigger neighbouring region of the study area. The bigger area is closely dissected by number of rivers and khals which are hydrologically connected to these major rivers.

The area represents mostly flat land with slight undulations and stands few meters higher than the surrounding area. A large part of this city is covered by low-lying depressions. The area represents significant variation in elevation ranges from 1.5 to $15 \mathrm{~m}$ with an average of $6 \mathrm{~m}$ above PWD (Public Works Datum) (+/- 0.45 meter with respect to mean sea level). The area slopes towards southeast, east and west, but general slope is from the north to southeast where the ground surface merges gently with the floodplains of the Buriganga River. The ele- 
vation of the surrounding floodplains of the area is variable. The average elevation of the Buriganga and the Lakhya River floodplains are about $3 \mathrm{~m}$ above the PWD.

The metropolis and its surrounding areas are covered with Pleistocene Madhupur clay and Holocene sediments of floodplain origin [24]. Holocene sediments are forming different types of landform in the area like: abandoned channels, depression, floodplain, high floodplain ( Figure 1). The western part of the investigated area is the main old city founded on the semi-consolidated Pleistocene sediments (Madhupur clay), slightly elevated than the extreme western edge, which is covered by the Buriganga-Turag floodplain sediments of Holocene to recent time [cf. 23]. The eastern edge is mainly covered by the floodplains of the Balu River. These floodplains are characterized by low-lying depressions and marshy areas which remain inundated during significant period of the year. To the east, the low-lying area (depression and floodplain in Figure 1) is covered with recent floodplain deposits. There are number of lakes, channels and khals in the city, which are connected to the surrounding rivers. The city is crossed by several faults and lineaments which are possibly controlling the orientation of rivers and streams [25]. The downthrown subsiding blocks are hosting marshy and swampy lands i.e. wetlands habitats $[5,23]$.

The storm runoff accumulates in the low-lying areas, flows through khals and local rivers and ultimately discharges to the major rivers. These lowlands and wetlands are performing important drainage function by storing storm water and keep the relatively higher lands free from rainfall flooding [12]. The area has a tropical monsoon (May to October) climate like other part of the country with an average precipitation of $2000 \mathrm{~mm} /$ year.

\section{Approach and Methodology}

\subsection{Defining Wetland and Approach}

The RAMSER convention has defined wetlands as "areas of marsh, fen, peatland or water, whether natural or artificial, permanent or temporary, with water that is static or flowing, fresh, brackish or salt, including areas of marine water the depth of which at low tide does not exceed six meters" [cf. 3]. According to Khan et al, [26] wetland holds water for a significant duration sufficient to support organism adapted to life in inundated or saturated soil condition and consists of wide variety of types ranging from lakes, rivers and coastal forest to deepwater paddy fields and ponds. The built-up area of the city is traversed and surrounded by wetlands of different types. For the purpose of the study, these wetlands are subdivided into three categories:

1) Open water body comprises marshy and peaty inundated (during significant part of the year) low-lying areas of the Turag-Buriganga and the Balu floodplains.

2) Inland water body includes the lakes and connecting canals of different water bodies in the city area.

3) Fluvial water body denotes the surrounding rivers (Turag, Buriganga, Balu River and Tongi Khal) of the city.

It is however, analyses were done for the open and inland water bodies only. Third category was not included in the analysis as because this needs to be done with high resolution imagery with extensive field verifications. This is also out of the scope of the current work.

\subsection{Data and Software Used}

In order to compare the water bodies, two digital images: aerial photo of 1968 and SPOT satellite image of 2001 were used. Aerial photo of 1968 is a panchromatic type image with spatial resolution 12 metres (scanned resolution), has been considered for pre-urban state water body analysis. On the contrary, a multispectral SPOT image acquired in 27 December 2001 with 20 metres spectral resolution has been used to map the water-bodies of urbanised state of the city. The exact timing of the aerial photography has not been found with the image. However, it was revealed from the source organization that these images taken during the dry season around December-January time of the year. The temporal variation in the extent of the water-bodies is assumed to be insignificant over 1-2 months, at least for city-wide change analysis. However, this could be a source of uncertainties in the current analysis, in addition to the comparison of the two different spatial resolutions of the images. The data layers (containing the areas of water bodies) of two years were overlaid to reveal the changes.

There are two strips of the aerial photograph to covers the study area. The aerial photographs did not have cartographic standard and three-dimensional geographic distortions were found. The study has been carried out under the framework of Geographic Information System (GIS). The Image Processing tasks have been carried out using Earth Resource Data Analysis System (ERDAS) 8.4 image processing software (Leica Geosystems Geospatial Imaging, LLC, Norcross, USA). Data on wetland features has been extracted using ERDAS imagine software. GIS analysis has been carried out using ArcInfo software (ESRI, Redlands, California, USA) and the outputs have been generated using ArcView 3.3 software (ESRI, Redlands, California, USA).

\subsection{Data Processing and Analysis}

Data processing and analysis scheme used for the study is illustrated using a flow chart as in Figure 2. The SPOT image of 2001 was collected in ERDAS Imagine (*.img) format. This image was loaded into computer memory 


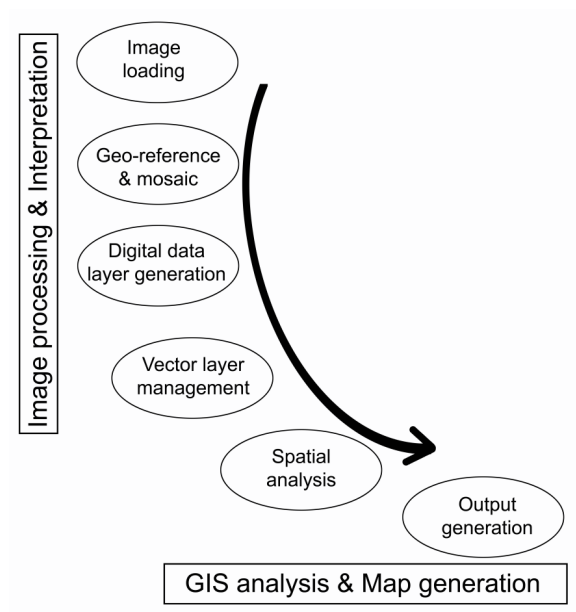

Figure 2. Data processing and analysis stages followed during the study.

directly from the $\mathrm{CD}$ (compact disk). Aerial photographs of 1968 were collected in the bitmap (*.bmp) format. These photographs were imported to *img format to process the data using ERDAS Imagine software.

Geo-referencing was performed to render real world coordinates to the images to avoid geometric distortion. Aerial photographs of 1968 contain multi-scale geometric distortion. For geo-referencing of this image, fourth order polynomial transformation was used based on 112 GCPs. For better mutual registration of the two data images, GCPs for the aerial photograph were derived from the geo-referenced SPOT image. The SPOT image of 2001 does not contain multi-scale geometric distortion; thus second order polynomial transformation was used for this image. For calculating the transformation matrix, 16 Ground Control Points (GCP) were used. The GCPs were derived from a geo-referenced image. Remarkable features, like road junctions, river bend etc., common to both images (1968 and 2001) were used as GCPs. In case of rivers or lakes, GCPs were chosen in the middle of the channel. Because most of the (spatial) changes to these features occurred at the edges of the channels or lakes (see Section 4). It should point-out here that the lakes in the study area are also channel-like (relict channel) features. The projection system used for the images was Lambert Conformal Conic (LCC). The geo-referenced two strips of aerialphotos were mosaic to obtain the image of the whole study area. Then thematic data layers were generated from the geo-referenced images using on-screen digitization technique. Data layers were generated in ArcInfo vector format using the digitization tools of ERDAS Imagine software. ArcInfo vector data layers generated from the images to render the GIS standard of the data.

The spatial analyses of the thematic data layers were performed to generate composite data layers from the two images. Aerial coverage of individual type of water body for the year 1968 and 2001 was calculated and the disparities between them were estimated. Changes were illustrated through map generation using ArcView software as described in result section.

\section{Results}

\subsection{Open Water Body}

Analysis of aerial photo of 1968 revealed (Figure 3) that most of the eastern part of Dhaka city is covered by open water bodies in the form of the marsh-land or peaty areas of the Balu River floodplain. Western edge of the city is also covered by the marshy low lands. These low lands in the west of Muhammadpur and northwest of Pallabi are generated within the floodplain of the Buriganga and the Turag River. Marshy land of the Turag floodplain extended into the built up area (mostly the Madhupur Clay covered area in Figure 1) in the northwest part of the city near Pallabi. The total area is measured as $133.03 \mathrm{~km}^{2}$. Satellite image of 2001 (Figures 4 and 5) shows that the coverage of the water bodies in the eastern part of the city has been reduced and became sporadic. The water bodies in the western edge of the city are also reduced and become patchy. The total area is measured $67.79 \mathrm{~km}^{2}$ in 2001.

\subsection{Inland Water Body}

Lakes, channels and khals, which are visible on the images, have been identified. The inland water bodies on the aerial photo of 1968 are more prominent than 2001. Analysis and observation for inland water body on 1968 image show that the Gulshan Lake, Dhanmondi Lake and Ramna Lake are highly visible (Figure 3). Some channels and/or khals are also identified in different parts of the city. Channels are located in the northeastern, eastern, southwestern, southern and north-western corner of the city. The total areas of inland water body are measured $5.1 \mathrm{~km}^{2}$. Analysis of satellite image of 2001 (Figure 4 and 6) for inland water body shows that the areas of lakes (Gulshan and Dhanmondi) have shrunken and narrowed down. Some khals and channels are not identifiable or missing in the southwestern (Muhammadpur) and southern (Motijheel) area of the city and the total area is measured $1.8 \mathrm{~km}^{2}$ in 2001 .

\subsection{Water Body Compartmentalization}

In most part of the city open water bodies were acting as a single water body and were well in connection with the surrounding river via streams and khals. It is seen that water bodies become more sporadic and patchy in 2001 in compare of 1968 in many part of the city (Figure 5). Water body compartmentalization, specifically, occurred 


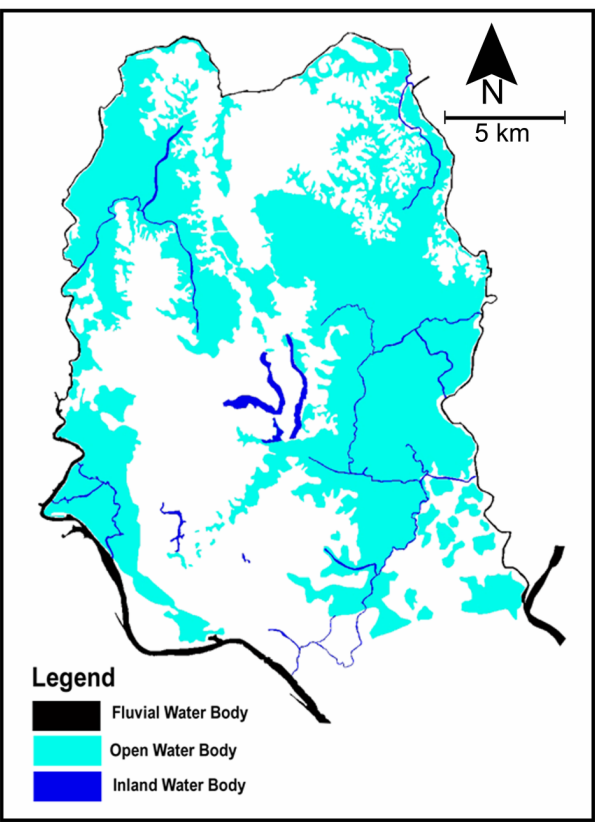

Figure 3. Spatial coverage of different types of water bodies in the year 1968 .

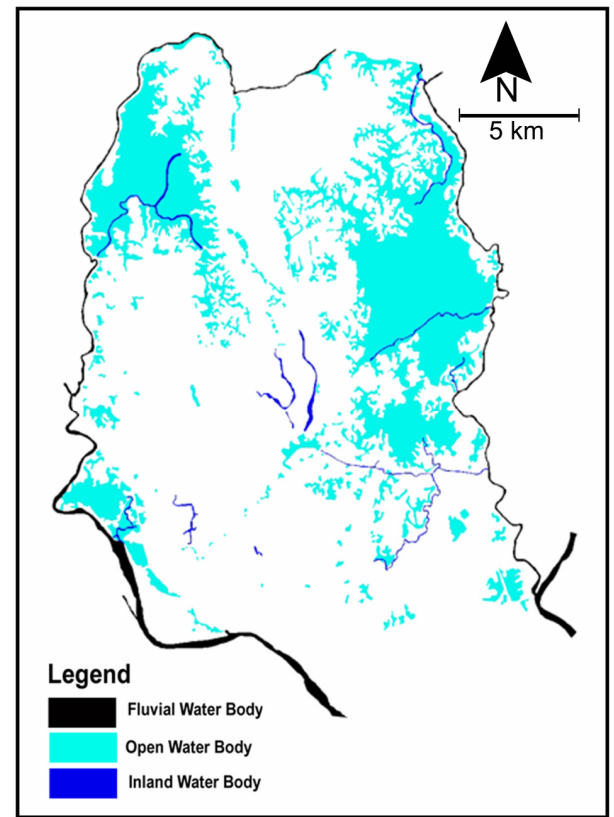

Figure 4. Spatial coverage of different types of water bodies in the year 2001.

in the north central (Figure 7), southeast and western part of the city.

\section{Discussions}

\subsection{Reduction of Wetland Area}

Analysis revealed that area covered by wetlands in the

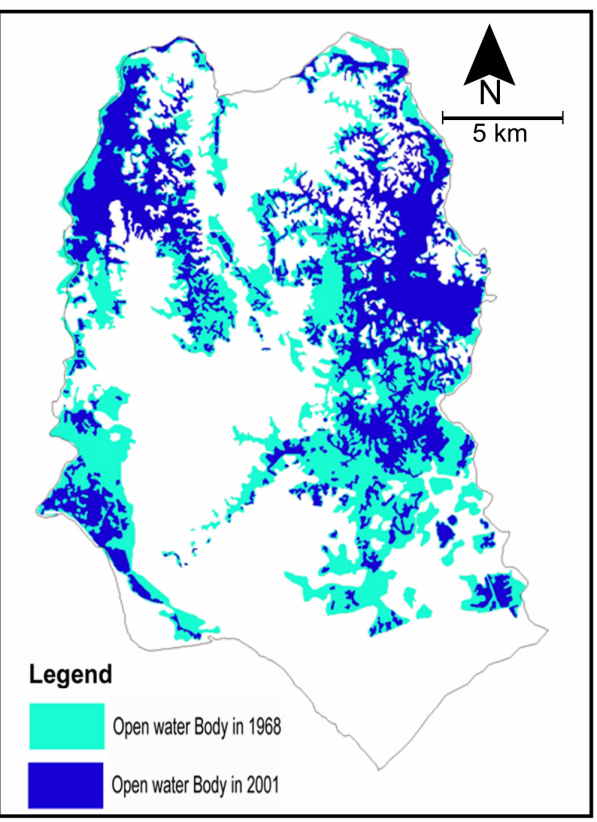

Figure 5. Disparity of open water body between the year 1968 and 2001.

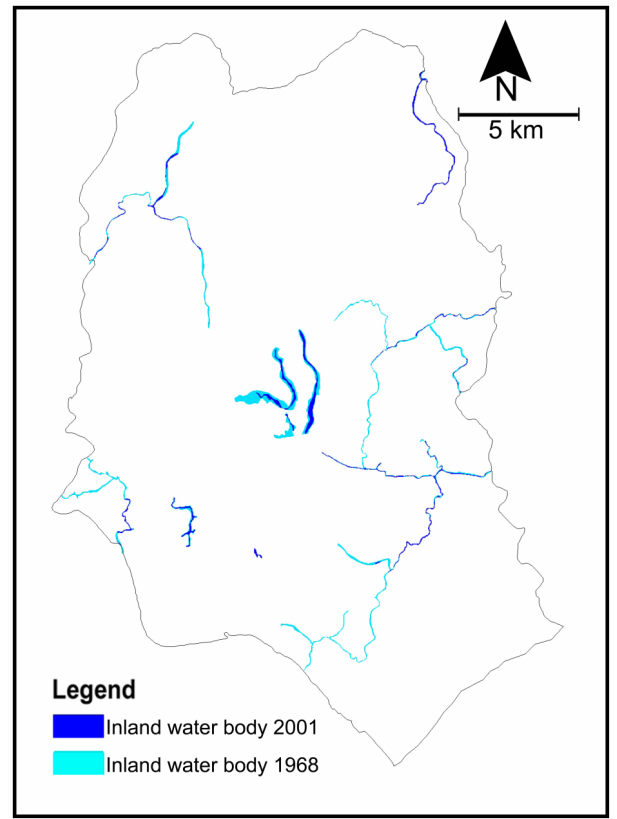

Figure 6. Overlay of inland water body of the year 1968 and 2001, showing the differences.

city significantly reduced over the period 1968 to 2001 (Table 1). In 1968, the area of the open water body was $133 \mathrm{~km}^{2}$, which became $\sim 68 \mathrm{~km}^{2}$ in the year 2001 . The amount of the open water body reduction is $\sim 65 \mathrm{~km}^{2}$. The wetlands in the south-western corner retreat towards the Turag River in between Mirpur and Muhammadpur area. Minor reduction of the wetland has been occurred in the Pallabi-Cantonment area as well (Figure 5), where 


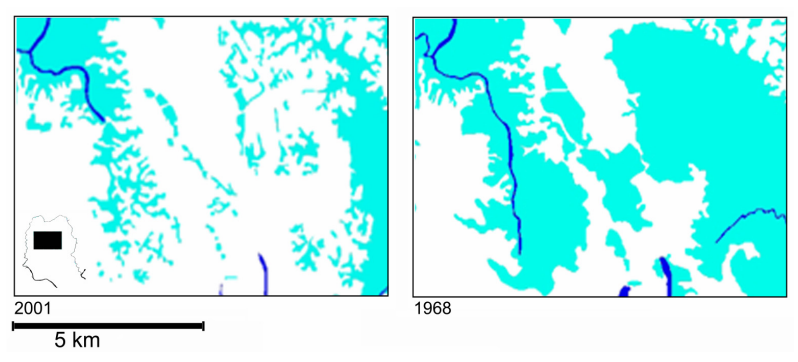

Figure 7. Water body compartmentalization in the north central part (please see marked black-rectangle in the inset for index) of the city. This sort of partitioning can also be seen in the south central and many others parts of the city through close observation in Figures 3 and 4.

Table 1. Summary of analysis on the changes in water bodies.

\begin{tabular}{lcc}
\hline Item/ Class & Open Water Body $\left(\mathrm{km}^{2}\right)$ & $\begin{array}{c}\text { Inland Water Body } \\
\left(\mathrm{km}^{2}\right)\end{array}$ \\
\hline Area in 1968 & 133.03 & 5.1 \\
Area in 2001 & 67.79 & 1.8 \\
& -65.24 & -3.3 \\
Change in area & $(50.96 \%)$ & $(64.7 \%)$ \\
(Change in \%) & '- sign in change in area row indicate lose in area compare to 1968 \\
Total area of the city is $298.26 \mathrm{~km}^{2}$ &
\end{tabular}

low-lying areas were filled and levelled for the urban extension. The reduction of wetland in this area closely matches the ground filling in Dhaka city as described in earlier works, e. g. [10,11].

The area of the inland water body was found to be 1.8 $\mathrm{km}^{2}$ in the year 2001 which was $5.1 \mathrm{~km}^{2}$ in 1968 . The reduction of area in the inland water body was $3.3 \mathrm{~km}^{2}$. The shape of the water bodies remains almost same; but the widths of the lakes - Gulshan and Dhanmondi have been reduced (Figure 6). Inland water body has been mostly changed by the land filling and storm- and waste- water laid deposits. There are high-rise buildings constructed by the bank of these lakes encroached part of the lake area in some parts. Some of the channels in southeastern neighboring region of Motijheel area are not identifiable or missing in the 2001. These are narrowed or lost due to either encroachment or acquisition by government for construction of roads, box culverts or underground drains. These require ground truth and/or onsite mapping.

Urban expansion has been encroaching in the low- lying areas to cope with population growth, is the main reason for the reduction of wetland areas in the city. From the history of growth of the city, e. g. [22] demonstrated that the city was remaining almost same up to the late 1980s. Earlier study, Reza and Alam [13] showed that area of water bodies in the western part of the city reduced to $91 \%$ of 1963 in 1990, which dropped to $63 \%$ of 1963 in 2000. In the present study the change in open water bodies over the entire metropolitan area is calculated to be reduced by $51 \%$ in the year 2001 compare to 1968. It can be opined that this reduction happened in the 1990s too. From the earlier work e.g. [14], it is vivid that the city areas in the early 1990s were extending the western low-lying areas while in the late 1990s and as well as in the 2000s the urbanization activities redirected to the eastern wetlands.

\subsection{Significance of Wetland}

Wetlands associated with river-floodplain system capture and retain water, reducing the duration and severity of floods [3]. Inland wetlands intercept surface flow and slow it down, reducing the potential for floods. In the city development master plan [9], wetlands in the eastern part were proposed as retention basin, which has long been acting so to keep Dhaka free from rainfall- storm flooding. The unplanned urban extension into these wetlands may be causing water-logging problem during wet-season in the eastern part of the city [14]. This unplanned urbanization has also resulted into compartmentalization of the wetland. Due to poor connectivity between the different compartments of the wetland are causing water-logging in the built-up area as well. Water quality of the wetland would have been progressively deteriorating as wetland gets patchy and isolated.

The extent of groundwater recharge by a wetland is dependent upon soil, vegetation, site, perimeter to volume ratio, and water table gradient [27]. The soil under most wetlands in Dhaka city is relatively impermeable; however, perennial presence of these wetlands may signify their potential contribution to groundwater recharge. Moreover, some wetlands particularly around the built-up area have lesser thickness of silty-clay at the bottom; have the higher potential to groundwater recharge. The wetlands around the built-up area and rivers around the city have found to play a significant role in the groundwater recharge $[28,29]$. Demand driven abstraction of groundwater in the city has been failing to balance with amount of recharge in the recent years leading declining groundwater level and aquifer dewatering in many parts [30]. This may have been further enhanced by the reduction of wetland area.

\section{Conclusions and Management Implications}

Infilling of natural channels and lowlands for urban infrastructure have been reducing the area, and compartmentalizing the water bodies which causing water loggings and flood hazards in various parts of the city. Among the different types of water bodies marshy and peaty inundated low-lying areas, natural retention basin around the city, are the hardest hit by the unplanned urbanisation. In 1968 , the total area of marshy and peaty inundated 
low-lying areas was $133 \mathrm{~km}^{2}$, which was found to be $\sim 68$ $\mathrm{km}^{2}$ in the year 2001. Over the last 33 years (1968 to 2001) $50 \%$ of the wetlands have been reduced. If the reduction rate $\left(\sim 2 \mathrm{~km}^{2}\right.$ per year) remained in place, the total wetland area in the year 2009 would be $\sim 50 \mathrm{~km}^{2}$. This means the wetland area may have reduced further from ' $50 \%$ of 1968 ' in 2001 to ' $37 \%$ of 1968 ' in 2009.

Most of the wetland losses in the eastern part of the city are associated with an urgent need for shelter by the less-favoured urban population, and growth takes the form of informal settlements. In the long run these informal growths are destroying the wetland ecology, reducing the area, and segmenting the integrity of the wetlands. Wetland loss can be viewed in several ways. The most obvious type of wetland loss is the conversion of a jurisdictional wetland to a non-jurisdictional status [21]. For an example, wetlands in the northwest corner of the city (between Kafrul and Mirpur on Figure 1) have been acquired for the development of government offices over the last two decades. These wetland losses could be stopped if these were jurisdiction wetland instead of nonjurisdiction type. In Dhaka city wetlands should be classified as jurisdictional, and conserved by a regulatory board to preserve and restore the wetlands.

It is true that urbanization in Dhaka city would not be stopped, but these should be based on further specific studies and understanding of the hydrological system of the area, not just demand driven unplanned expansion. In addition, drainage in Dhaka city is strictly controlled by land-relief and hence by gravitational drainage. Special care should be given to the development and alteration of the existing water bodies so that natural hydrological condition can cope to the artificial structural actions. Water management must be the first concern for any development in Dhaka city because of its natural settings, and almost all the time people suffer from water and/or for water in a growing mega city.

\section{Acknowledgement}

Support for this work came from the Bangladesh University of Engineering \& Technology (BUET) as student research grants. We thank Mr. Mohammad Hoque, Mr. Mohammad Shamsudduha, and an anonymous reviewer for their comments on the manuscript. CEGIS and SPARRSO are highly appreciated for providing the images and processing facilities respectively.

\section{References}

[1] H. C. Brookfield, et al., "The new great age of clearance and beyond: What sustainable development is possible?" University of California Press, Berkeley, 1988.

[2] L. K. Sire and G. Balamurugan, "Urbanization and urban water problems in Southeast Asia a case of unsustainable development," Journal of Environmental Management,
Vol. 32, pp. 195-209, 1991.

[3] P. J. Dugan, et al. "Wetland conservation: a review of current issues and required action," International Union for the Conservation of Nature and Natural Resources Gland (IUCN), Switzerland, 1990.

[4] L. Wang, W. D. Wang, Z. G. Gong, Y. L. Liu, and J. J. Zhang, "Integrated management of water and ecology in the urban area of Laoshan district, Qingdao, China," Ecological Engineering, Vol. 27, pp. 79-83, 2006.

[5] UN, "Urban geology of Dhaka, Bangladesh, economic and social commission for Asia and the pacific, Atlas of Urban Geology," United Nation (UN), New York, 1999.

[6] M. Alam and M. G. Rabbani, "Vulnerabilities and responses to climate change for Dhaka," Environment and Urbanization, Vol. 19, pp. 81-97, 2007.

[7] BBS, 2004-Statistical Yearbook of Bangladesh, Bangladesh Bureau of Statistics (BBS), Ministry of Planning, Government of People's Republic of Bangladesh, Dhaka, 2004.

[8] J. E. Morgan and W. C. McIntire, "Quaternary geology of Bengal Basin, East Pakistan and India," Geological Society of America Bulletin, Vol. 70, pp. 319-342, 1959.

[9] JICA, "Master plan for greater Dhaka protection project (Study in Dhaka metropolitan area)," Japan International Cooperation Agency (JICA), Dhaka, 1991.

[10] A. S. M. M. Kamal and S. Midorikawa, "GIS-based geomorphological mapping using remote sensing data and supplementary geoinformation: A case study of the Dhaka city area, Bangladesh," International Journal of Applied Earth Observation and Geoinformation, Vol. 6, pp. 111-125, 2004.

[11] N. Shams, "Urban geology of Dhaka city for geohazard mitigation and development planning," M. Sc. thesis, University of Dhaka, Dhaka, Bangladesh, 1999.

[12] J. U. Chowdhury, R. Rahman, S. K. Bala, and A. K. M. S. Islam, "Impact of 1998 flood on Dhaka city and performance of flood control works," Integrated Water Flow Model (IWFM), Bangladesh University of Engineering \& Technology (BUET), Dhaka, 1998.

[13] A. N. M. G. Reza and M. S. Alam, "Wetland transformation in the western part of Dhaka city (1963-2000)," Bhugal Patrika (Journal of Geography), Vol. 21, pp. 23-40, 2002.

[14] A. M. Dewan, K. T. M. Nishigaki, "Flood hazard delineation in greater Dhaka, Bangladesh using an Integrated GIS and remote sensing approach," Geocarto International, Vol. 21, pp. 33-38, 2006.

[15] J. U. Chowdhury, M. M. Kamal, N. I. Khan, and M. A. Salam, "Impact of land use change upon storm water drainage and wetlands in the eastern part of Dhaka city," Integrated Water Flow Model (IWFM), Bangladesh University of Engineering \& Technology (BUET), Dhaka, Bangladesh, 2001.

[16] O. Mark, T. van Kalken, K. Rabbi, and J. Kjelds, "A mouse GIS study of the drainage in Dhaka city," Surface Water Modeling Center (SWMC), Dhaka, Bangladesh, 2001.

[17] K. G. Tawhid, "Causes and effects of water logging in 
Dhaka city, Bangladesh," TRITA-LWR Master thesis, Department of Land and Water Resource Engineering, Royal Institute of Technology (KTH), 2004.

[18] M. N. Islam, "Rainfall and temperature scenario for Bangladesh," The Open Atmospheric Science Journal, Vol. 3, pp. 93-103, 2009.

[19] S. Rahman and F. Hossain, "Spatial assessment of water quality in peripheral rivers of Dhaka city for optimal relocation of water intake point," Water Resources Management, Vol. 22, pp. 377-391, 2008.

[20] W. J. Mitsch, R. H. Mitsch, and R. E. Turner, "Wetlands of the old and new worlds: ecology and management," In Global Wetlands: Old World and New, Elsevier Science B. V., Amsterdam, 1994.

[21] D. F. Whigham, "Ecological issues related to wetland preservation, restoration, creation and assessment," The Science of the Total Environment, Vol. 240, pp. 31-40, 1999.

[22] N. Islam, "Dhaka: from city to mega city," The University of Dhaka, Dhaka, Bangladesh, 1996.

[23] WASA, "Dhaka regional groundwater and subsidence model," Dhaka Water Supply and Sewerage Authority (WASA), 1991.

[24] M. K. Alam, A. K. M. S. Hasan, M. R. Khan, and J. W. Whitney, "Geological map of Bangladesh," Geological Survey of Bangladesh, Dhaka, Bangladesh, 1990.

[25] R. A. Khandoker, "Origin of elevated Barind-Madhupur areas, Bengal basin: Result of neotectonic activities," Bangladesh Journal of Geology, Vol. 6, pp. 1-9, 1987.

[26] M. S. Khan, E. Huq, A. A. Rahman, S. Huq, S. M. A. Rashid, and H. Ahmed, et al., "Wetlands of Bangladesh," Bangladesh Centre for Advanced Studies (BCAS) in association with Nature Conservation Movement (NACOM), Dhaka, Bangladesh, 1994.

[27] T. C. Winter, "Relation of streams, lakes, and wetlands to groundwater flow systems," Hydrogeology Journal, Vol. 7, pp. 28-45, 1999.

[28] K. M. Ahmed and W. G. Burgess, "Surface water and groundwater interaction in Bangladesh hydrogeology," In Groundwater resources and development in Bangladesh background to the arsenic crisis, agricultural potential and the environment, A. A. Rahman, P. Ravenscroft, et al., Bangladesh Centre for Advanced Studies, University Press Ltd., Dhaka, Bangladesh, 2003.

[29] W. G. Darling, W. G. Burgess, and M. K. Hasan, "Isotopic evidence for induced river recharge to the Dupi Tila aquifer in the Dhaka urban area, Bangladesh," In The application of isotope techniques to the assessment of aquifer systems in major urban areas, TECDOC 1298, International Atomic Energy Agency (IAEA), Vienna, 2002.

[30] M. A. Hoque, M. M. Hoque, and K. M. Ahmed, "Declining groundwater level and aquifer dewatering in Dhaka metropolitan area, Bangladesh: causes and quantification," Hydrogeology Journal, Vol. 15, pp. 1523-1534, 2007. 